\title{
Computer Dependence and Internet Addiction as One of the Conflict Factors in a Modern Family
}

\author{
Valiullina L.M. \\ Psychological Centre «School of Life and Relations» \\ Kazan, Russia \\ angkazan@rambler.ru \\ Gryaznov A.N. \\ University of Management «TISBI» \\ Kazan Law Institute \\ University of the Office of the Prosecutor of the Russian \\ Federation \\ Kazan, Russia \\ angkazan@rambler.ru
}

\author{
Khayrullina A.R. \\ University of Management «TISBI» \\ Kazan, Russia \\ alya_khairullina@mail.ru \\ Baskakova V.E. \\ University of Management «TISBI» \\ Kazan, Russia \\ baskakovavasilisa@mail.ru
}

\begin{abstract}
The manuscript of this scientific article presents a universal author's definition of a person's dependence on gadgets. The diversity of the following aggressions are identified as verbal, physical, objective, emotional and self-aggression, and the levels of aggressiveness and adaptiveness are determined. The degree of Internet addiction and anxiety of a dependent person are revealed. It is indicated that the wealth of high technologies, designed to facilitate the life of a modern person, is fraught of escaping from reality into a world of virtual impressions. The virtual reality increasingly displaces everyday life, which affects the interparental relationships in a modern family, causing proneness to conflict, state anxiety and aggressiveness among relatives and loved ones in the family. There are factors that demolish the family pillars - these are addictions, such as alcoholism, drug addiction, computer and Internet addiction. It has been proved that computer and Internet addiction lead to a distorted self-perception and retreating the objective reality. Such an addiction entails the social and labor maladaptation, causes to lose bearings of differentiated and adequate self-image. It transfers the pole of communicative activity from the real conditions of society to the network, which inevitably leads to autization. In fact, after taking the training on prevention of computer and Internet addiction, the level of Internet addiction among family members decreased.
\end{abstract}

Keywords - addiction; addictive behavior; gadget; dependence; Internet addiction; maladaptation; autization; verbal aggression; physical aggression; subject aggression; emotional aggression.

\section{INTRODUCTION}

The relevance of this scientific manuscript is obvious. The President of the Russian Federation Vladimir Putin once again emphasized that the family plays a key role in raising the personality of the child. The President accented this at the meeting with schoolchildren, who were the authors of the best essays on the topic "Russia, looking to the future". In particular, he said: "I would like to draw attention to the family values, which are very important. It really matters, and it means a lot that you outlined it in your essays, as well as other topics." According to Vladimir Putin, "the absence of loved ones, the parental absence does not make a young man, a child, and then an adult full-fledged" $[9,10]$. And also Vladimir Putin has remarked upon the importance of instituting a family, emphasizing that the family is the keystone. It is in the family circle that the first civic, patriotic feelings are instilled, the atmosphere, in which the child's personality and worldview is formed, is created. The more families live in peace and harmony, the more humane, moral and stronger our society is" the President's address says [9]. One of the many factors that erode the family pillars is addiction, such as alcoholism, drug addiction, computer and Internet addiction. Computers, gadgets and the Internet are tightly woven into the life of a modern person, which, on the one hand, significantly simplifies the lives of most people, saving a lot of time: quick information search, making purchases, communicating, running errands just onsite, making it easier to solve training and professional tasks. However, on the other hand, many people take along their PCs on vacation and cannot imagine their lives without email, social networks and online games for few days.

Thus, the wealth of high technologies, designed to facilitate the life of a modern person, is fraught of escaping from reality into a world of virtual impressions. The virtual reality increasingly displaces everyday life, which affects the interparental relationships in a modern family, causing proneness to conflict, state anxiety and aggressiveness among relatives and loved ones in the family. Psychological trauma, that affects human behavior during a lifetime, appears in addictive family $[4,7,8]$. 
Theoretical and methodological basis of the study includes the provisions of psychological theory of activity (A.N. Leontyev, B.F. Lomov, S.L. Rubinstein), psychology of addictive behavior A.N. Gryaznov, E.V. Zmanovskaya, V.D. Mendelevich, A.E. Voyskunsky, K. Yang.

\section{RESULTS}

The research reveals levels of Internet addiction in studied groups. Averaged values of Internet addiction levels are detected. The level in experimental group is 80.95 , in control group- 63,3 .

The analysis of the data shows that the average values of the Internet addiction indicator differ in studied groups. To assess the significance of differences, a comparative analysis is carried out, the results of which are presented in Table 1.

Averaged profiles of the behavioral style in conflict, stressful situations and features of adaptiveness in the social environment (acts of aggressiveness) are presented in Figure1.

other hand, they create the conditions for substitution real by immersion into the virtual life that has a negative impact on an individual, family and society. This topic is especially acute among young people. There is an urgent need for a sociopsychological impact on the addictive personality, restructuring the personality by replacing addictive personal statuses with socially significant ones $[1,2,3,4,5]$. Hence the following research problem: what are the features of the prevention of computer and Internet addiction among family members.

The aim of research: to identify the prevention features of computer and Internet addiction among family members (spouses). To develop a program on reducing the level of addictive behavior among family members.

Object of research: the process of preventing computer and Internet addiction among family members.

Subject of research: socio-psychological aspects of prevention of computer and Internet addiction among family members.

Research hypothesis: the organization of successful preventive and corrective work on computer and Internet addiction among family members decreases the level of addictive behavior (anxiety, aggressiveness), which entails the creation of a strong family, minimization of conflict situations, effective formation of harmony developed personality, leading a healthy lifestyle.

\section{RESEARCH METHODOLOGY}

- «Internet Addiction Test», K. Yang (1994);

- «Anxiety Scale», J. Taylor (MAS) adapted by V. Norakidze;

- «Test for diagnostics of aggression» developed by L.G. Pochebut

A study sample includes 20 woman and 20 men aged from 20 to 30 .

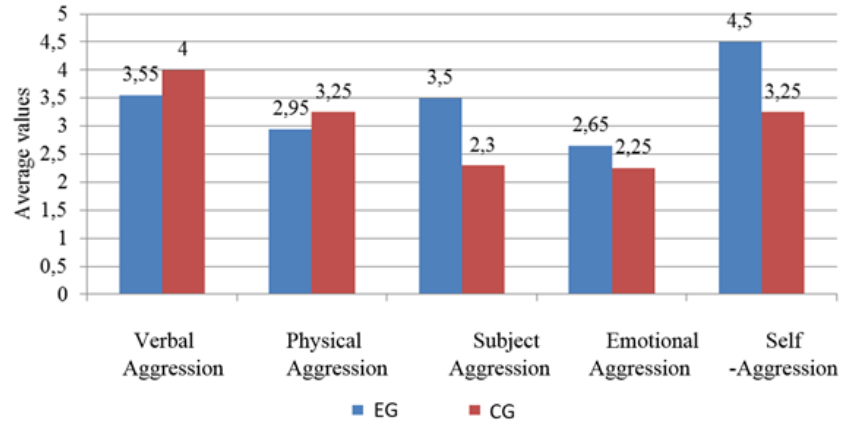

Fig. 1. The averaged profiles of the behavioral style in stressful situations and the features of adaptiveness in the social environment

Thus, statistically significant differences are established in the assessment of the indicator of Internet addiction, subject aggression, and self-aggression. The level of Internet addiction, subject aggression and self-aggression, anxiety is higher in experimental group.

The next step consists of brief description of the formative stage of the experiment: approbation of the program of sociopsychological training on prevention of computer and Internet addiction among family members.

Upon completion of approbation of training program in the experimental group, the control stage of the experiment was carried out, involving a comparative analysis of the studied parameters in the studied groups. 
TABLE I. EMPIRICAL VALUES OF T-CRITERIA OF STUDENT

\begin{tabular}{|c|c|c|c|c|c|c|}
\hline Groups & \multicolumn{2}{|c|}{ Experimental group } & \multicolumn{2}{|c|}{ Control group } & \multicolumn{2}{c|}{$\begin{array}{c}\text { Comparative } \\
\text { analysis }\end{array}$} \\
\hline Scales & Average & $\begin{array}{c}\text { Statistical } \\
\text { Deviation }\end{array}$ & Average & $\begin{array}{c}\text { Statistical } \\
\text { Deviation }\end{array}$ & $\begin{array}{l}\text { t- } \\
\text { empiric }\end{array}$ & $P$ \\
\hline $\begin{array}{c}\text { Indicator of } \\
\text { Internet } \\
\text { addiction }\end{array}$ & 80,95 & 26,22 & 63,10 & 9,50 & 2,918 & 007 \\
\hline $\begin{array}{c}\text { Verbal } \\
\text { Aggression } \\
\text { (VA) }\end{array}$ & 3,55 & 2,16 & 4,00 & 1,56 & 0,755 &, 455 \\
\hline $\begin{array}{c}\text { Physical } \\
\text { Aggression (PA) }\end{array}$ & 2,95 & 1,76 & 3,25 & 2,27 & 0,467 &, 643 \\
\hline $\begin{array}{c}\text { Subject } \\
\text { Aggression (SA) }\end{array}$ & 3,50 & 1,61 & 2,30 & 1,30 & 2,596 &, 014 \\
\hline $\begin{array}{c}\text { Emotional } \\
\text { Aggression } \\
\text { (EA) }\end{array}$ & 2,65 & 1,60 & 2,25 & 1,33 &, 860 & $\begin{array}{c}, 39 \\
6\end{array}$ \\
\hline $\begin{array}{c}\text { Self-aggression } \\
\text { (SA) }\end{array}$ & 4,50 & 2,16 & 3,25 & 1,68 & 2,039 & $\begin{array}{c}, 04 \\
9\end{array}$ \\
\hline $\begin{array}{c}\text { Level of } \\
\text { Aggressiveness } \\
\text { and } \\
\text { Adaptiveness }\end{array}$ & 17,10 & 6,56 & 15,05 & 4,38 & 1,162 &, 25 \\
\hline $\begin{array}{c}\text { Level of } \\
\text { Anxiety }\end{array}$ & 22,15 & 9,67 & 16,50 & 8,01 & 2,012 & $\begin{array}{c}, 05 \\
2\end{array}$ \\
\hline
\end{tabular}

The developed program includes psychodiagnostics of the level of Internet addiction, aggressiveness and anxiety. The aims of exercises are: mastering communication techniques, the formation of constructive ways of using computer and the capabilities of the Internet space, the recognition of emotions, the development of self-confidence and the formation of constructive strategies for interaction, love and mutual understanding, as well as program activities aimed at minimizing conflict situations in the family.

Control stage includes a comparative analysis of the results of empirical study. The research results are presented stepwise: 1) we determine the level of Internet addiction according to the methodology of K.Yang; 2) we study the acts of aggressiveness according to the methodology of L.G. Pochebut; 3) we identify the level of anxiety according to the Taylor scale. The results of the comparative analysis are presented in Table 2. We reveal the differences in studied indicators of family members and present the results of the study stepwise. The average values of the Internet addiction level in studied groups are presented in Figure 2. The obtained results show the differences. In order to prove these differences, the empirical value of Student t-criteria is calculated and reflected in Table 2.

Thus, the calculations show that the average value of the Internet addiction indicator in experimental group became significantly lower after approbation of the training, regarding the control group. There are no statistically significant differences in the assessment of Internet addiction in control group at ascertaining and control stages.

In view of the foregoing, we have formulated the conclusion that after participating in the training on prevention of computer and Internet addiction, the level of Internet addiction among family members decreased.

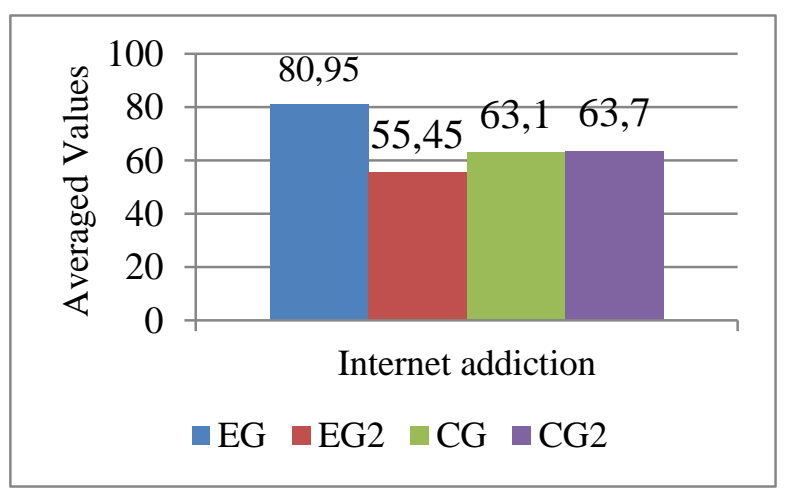

Fig. 2. The average values of " Internet addiction's levels»

The average profiles of the behavioral style in stressful situations and the features of adaptiveness in the social environment (acts of aggressiveness) are presented in Figure 3.

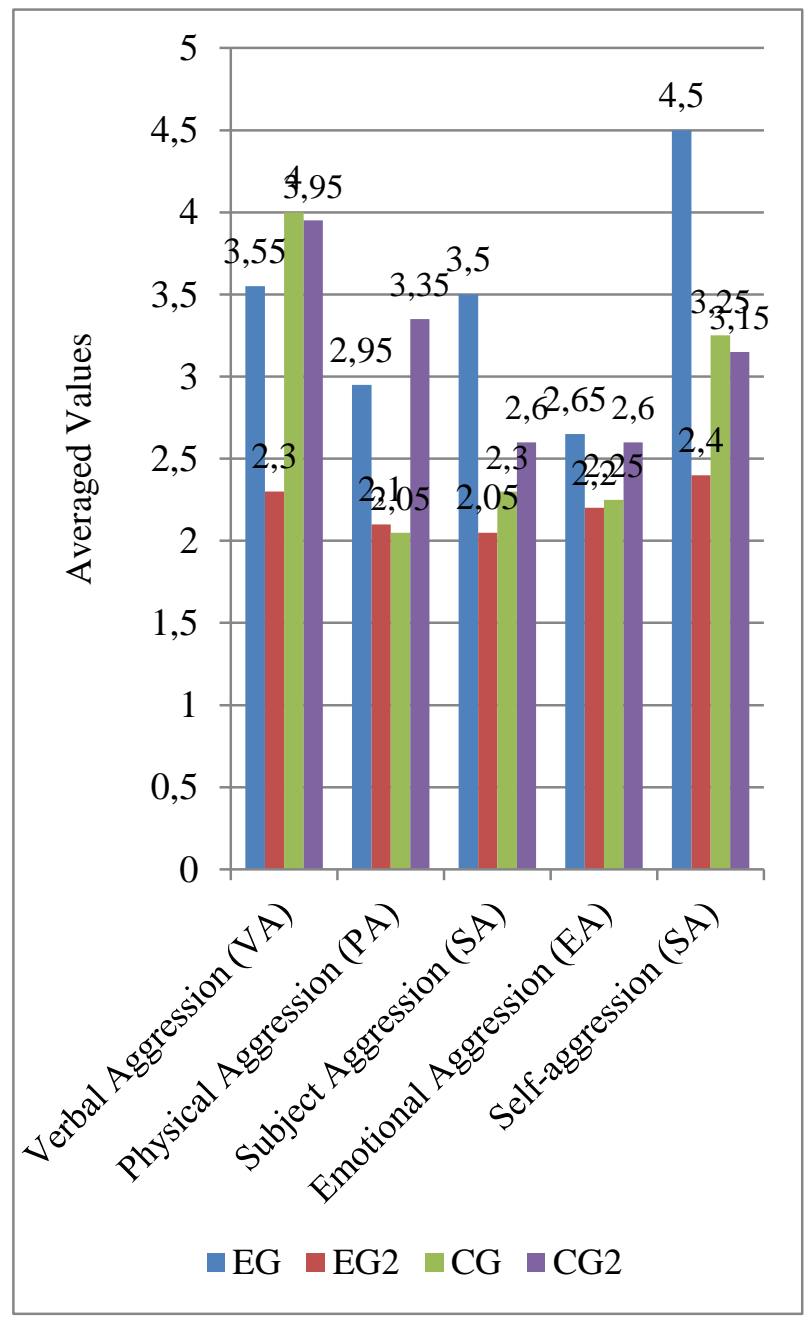

Fig. 3. The average profiles of the behavioral style in stressful situations and the features of adaptiveness in the social environment 


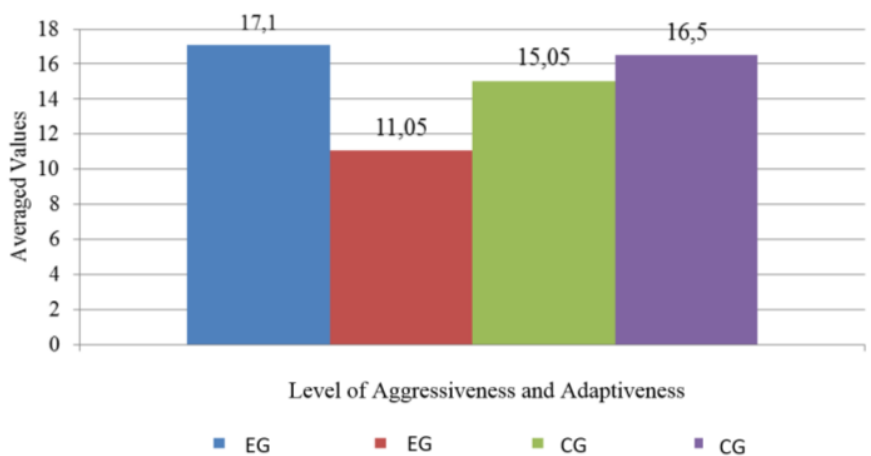

Fig. 4. The average values of the level of aggressiveness and adaptiveness

In view of the foregoing, we believe that the level of aggressiveness decreased after the participation of family members in training on prevention of computer and Internet addiction.

Analyzing the research results, we reveal the differences. In order to prove these differences, the empirical value of Student t-criteria was calculated and reflected in Table 2. The calculations show that the average value of the Internet addiction indicator in experimental group became significantly lower after approbation of the training, regarding the control group. There are no statistically significant differences in the assessment of Internet addiction in control group at ascertaining and control stages.

TABLE II. EMPIRICAL VALUES OF T-CRITERIA OF STUDENT

\begin{tabular}{|c|c|c|c|c|c|c|c|c|c|c|}
\hline Group & $\begin{array}{l}\text { In relation to the } \\
\text { experiment }\end{array}$ & Estimated data & $\begin{array}{l}\text { Indicator of } \\
\text { Internet } \\
\text { addiction }\end{array}$ & VA & PA & SA & EA & SA & $\begin{array}{c}\text { Level of } \\
\text { aggressiveness and } \\
\text { adaptiveness }\end{array}$ & Anxiety \\
\hline \multirow[t]{6}{*}{ Experimental } & \multirow[t]{2}{*}{ Before } & Average & 80,95 & 3,55 & 2,95 & 3,50 & 2,65 & 4,50 & 17,10 & 22,15 \\
\hline & & $\begin{array}{l}\text { Statistical } \\
\text { Deviation }\end{array}$ & 26,22 & 2,16 & 1,76 & 1,61 & 1,60 & 2,16 & 6,56 & 9,67 \\
\hline & \multirow[t]{2}{*}{ After } & Average & 55,45 & 2,3 & 2,1 & 2,05 & 2,20 & 2,40 & 11,05 & 15,00 \\
\hline & & $\begin{array}{l}\text { Statistical } \\
\text { Deviation }\end{array}$ & 15,14 & 1,30 & 1,21 & 0,76 & 1,20 & 1,27 & 3,73 & 6,29 \\
\hline & \multirow{2}{*}{ Comparative analysis } & t-empiric & 3,859 & 2,214 & 1,779 & 3,651 & 1,008 & 3,740 & 3,584 & 2,772 \\
\hline & & $\mathrm{p} \leq$ & 0,001 & 0,033 & 0,083 & 0,001 & 0,320 & 0,001 & 0,001 & 0,009 \\
\hline \multirow[t]{6}{*}{ Control } & \multirow[t]{2}{*}{ Before } & Average & 63,10 & 4,00 & 3,25 & 2,30 & 2,25 & 3,25 & 15,05 & 16,50 \\
\hline & & $\begin{array}{l}\text { Statistical } \\
\text { Deviation }\end{array}$ & 9,50 & 1,56 & 2,27 & 1,30 & 1,33 & 1,68 & 4,38 & 8,01 \\
\hline & \multirow[t]{2}{*}{ After } & Average & 63,70 & 3,95 & 3,35 & 2,60 & 2,60 & 3,15 & 15,65 & 17,40 \\
\hline & & $\begin{array}{l}\text { Statistical } \\
\text { Deviation }\end{array}$ & 9,24 & 1,36 & 2,01 & 1,19 & 1,19 & 1,50 & 3,96 & 7,24 \\
\hline & \multirow[t]{2}{*}{ Comparative analysis } & t-empiric & 0,203 & 0,148 & 0,761 & 0,877 & 0,199 & 0,454 & 0,454 & 0,373 \\
\hline & & $\mathrm{p} \leq$ & 0,841 & 0,883 & 0,451 & 0,386 & 0,844 & 0,652 & 0,652 & 0,711 \\
\hline \multirow{2}{*}{\multicolumn{2}{|c|}{$\begin{array}{l}\text { Comparative analysis of experimental } \\
\text { and control groups at control stage }\end{array}$}} & t-empiric & 2,081 & 3,925 & 1,707 & 1,061 & 1,745 & 2,385 & 3,777 & 2,119 \\
\hline & & $\mathrm{p} \leq$ & 0,046 & 0,000 & 0,096 & 0,295 & 0,089 & 0,022 & 0,001 & 0,017 \\
\hline
\end{tabular}

Note: Verbal aggression (VA), Physical aggression (PA), Subject aggression (SA), Emotional aggression (EA), Self- aggression (SA)

In view of the foregoing, we have formulated the conclusion that after participating in the training on prevention of computer and Internet addiction, the level of Internet addiction among family members decreased.

\section{CONCLUSION}

Computer and Internet addiction may lead to a distorted perception of personality and objective reality, which determines the social and labor maladaptation, prevents the formation of differentiated and adequate representations of self-image. There is a transfer of communicative activity from the real conditions of society into the network, which inevitably leads to autization.

Internet addiction leads to the development of such personality deformations as verbal, physical, emotional aggression and self-aggression, which affect the behavior of the individual. Building relationships in family, creating conflict situations. 
[5] Gerasimova V.V., Karpov A.M., Gryaznov A.N., Dergunova D.I. Valuecommunicative sphere of personality in auto-aggressive behavior. Bulletin of Psychiatry and Psychology of Chuvashia. 201,. 7, pp. 104115 .

[6] Gilemkhanova E.N., Gryaznov A.N., Shulaev A.V. Socio-psychological approach in understanding of adaptiveness. Neurological Bulletin. Magazine named after Behterev V.M. 2010, vol. 42, 2, pp. 33-37.

[1] Andreassen, Cecilie \& Pallesen, Ståle \& Griffiths, Mark. The relationship between addictive use of social media, narcissism, and selfesteem: Findings from a large national survey. Addictive Behaviors. 2016, p. 64. DOI: 10.1016/j.addbeh.2016.03.006.

[2] Saeyeldin A., Zafar M.A., Velasquez C.A., Ip K., Gryaznov A., Brownstein A.J., Ziganshin B.A., Elefteriades J.A., Li Y., Rizzo J.A., Erben Y. NATURAL HISTORY OF AORTIC ROOT ANEURYSMS IN MARFAN SYNDROME. Annals of Cardiothoracic Surgery. 2017, vol. 6, 6, pp. 625-632.

[3] Young K. The Evolution of Internet Addiction Disorder. In: Montag C., Reuter M. (eds) Internet Addiction. Studies in Neuroscience, Psychology and Behavioral Economics. Springer, Cham. 2017. DOI: https://doi.org/10.1007/978-3-319-46276-9_1

[4] Bashyrova T.N., Gryaznov A.N. Factors of Addictive Behavior of

University Students. Kazan Pedagogical Journal. 2011, 3(87), pp. 84-90.

[7] Gryaznov A.N Social psychology of an addictive personality. Kazan, 2007.

[8] Gryaznov A.N Tertiary socialization of the personality of patients with alcoholism and drug addiction. Doctor's thesis. Yaroslavl State University. P.G. Demidova. Yaroslavl. 2008.

[9] Gryaznov A.N., Khusainova S.V., Kharapal L.R., Cheverikina E.A. Activity's anxiety of an addictive personality as an element of the disruption of life safety. Kazan Pedagogical Journal. 2015, 1(108), pp. 115-120.

[10] Alexsandr S. Kuznetsov. Russian Professor's meeting. Russian Journal of Physical Education and Sport. 2019, 14(1), pp. 17-22. DOI: 10.14526/2070-4798-2019-14-1-18-24 